\title{
Influence of external pressure on conductivity of systems based on polyethylene oxide and carbon nanotubes
}

\author{
E.A.Lysenkov ${ }^{1}$, V.V.Klepko ${ }^{2}$ \\ ${ }^{1}$ V.Sukhomlynskiy Mykolayiv National University, 24 Nikol'ska Str., \\ 54030 Mykolayiv, Ukraine \\ ${ }^{2}$ Institute of Macromolecular Chemistry, National Academy of Sciences of \\ Ukraine, 48 Kharkiv Highway, 02160 Kyiv, Ukraine
}

Received April 9, 2016

\begin{abstract}
Features of conductivity of systems based on polyethylene oxide and carbon nanotubes depending on the value of external pressure are studied using method of impedance spectroscopy. It is revealed that dependence of conductivity on pressure shows percolation behavior. The mechanisms of nonlinear change of conductivity with the pressure increase are described and a scheme for their explanation is offered. It is shown that the investigated systems are perspective piezoresistive materials.

Keywords: polymer nanocomposites, carbon nanotubes, conductivity, percolation behavior, external pressure.

Используя метод импедансной спектроскопии проведено исследование особенностей электропроводимости систем на основе полиэтиленоксида и углеродных нанотрубок в зависимости от величины внешнего давления. Установлено, что зависимость электропроводимости от давления проявляет перколяционное поведение. Обнаружены механизмы нелинейного изменения електропроводимости с ростом давления, предложена схема для их объяснения. Показано, что исследуемые системы являются перспективными пьезорезистивными материалами.
\end{abstract}

Вплив зовнішнього тиску на електропровідність систем на основі поліетиленоксиду та вуглецевих нанотрубок. Є.Лисенков, В.Клепко.

Використовуючи метод імпедансної спектроскопії проведено дослідження особливостей електропровідності систем на основі поліетиленоксиду та вуглецевих нанотрубок у залежності від величини зовнішнього тиску. Встановлено, що залежність електропровідності від тиску проявляє перколяційну поведінку. Виявлено механізми нелінійної зміни електропровідності зі зростанням тиску, запропоновано схему для їх пояснення. Показано, що системи, які досліджено, є перспективними п'єзорезистивними матеріалами.

\section{Introduction}

Electrical conducting polymeric nanocomposites are the objects of intensive researches during the last twenty years. Considerable interest in such materials is caused by their unique properties which allow to apply nanocomposites in the different areas of industry [1]. Conducting fillers of different nature are used for creation of electrically conducting polymernanocomposite materials. The most perspective substances for the nanocomposites creation are carbon nanotubes (CNT) [2,3]. The charge transfer in systems, filled by CNT, is realized through electrical conducting clusters, which appear from nanotubes and pierce all 
volumes of polymeric matrix [4]. The nanocomposites have the unique electric and thermodynamics properties due to formation of percolation clusters from CNT in a dielectric medium, thus in general percolation threshold observed at the extraordinarily small concentrations of the CNT. The low percolation thresholds are characterized not only for the systems based on polymers, but for nanocomposites based on liquid crystals [5] and liquids [6].

As a result of applying of external mechanical tension, conducting net from nanotubes can distract, that leads to decrease of conductivity of the system, or, vice versa, it can become denser with formation of additional channels of the charge transfer that results in the conductivity increase [7]. Flexible nature of the polymeric materials allows them to carry out very large reversing deformations at the imposition of relatively small tension. Such features of the electrical conducting polymeric nanocomposites allow to apply them as piezoresistive materials [8].

Many researches devoted to tension sensors or piezoresistive materials based on the polymer-CNT systems are known from the literature. In most of these researches, dependence of electric descriptions from a tension for the polymeric nanocomposites, filled by CNT, is studied experimentally [9, 10]. Ramaratnam et al. investigated the properties of poly(vinylidene fluoride) (PVDF)-CNT system as dynamic sensors for vibration control [9]. Introduction of the CNT in the complement of piezoelectric PVDF considerably improved its electromechanics properties. Kang et al. investigated sensory properties of system based on poly(methyl methacrylate)-CNT [10]. It is shown that at small loading of the filler, the systems show linear dependence of conductivity from tension. However, at some critical values of the loading, conductivity decrease with the tension increase, that is explained by the sliding of bunches from the nanotubes. Park et al. presented dependences of electric descriptions from the relative elongation of nanocomposite materials based on polyethylene oxide (PEO) and CNT [11]. Investigated polymeric nanocomposites were contained 0.56 vol. \% (nearby the percolation threshold) and 1.44 vol. \% (far from the percolation threshold) CNT. It was shown that the dependences of resistance from elongation have linear and nonlinear areas. Except it, PEO-CNT system were characterized by the very low percola- tion threshold, which lies in the range from 0.1 to $0.5 \%$ [12-14]. Nanocomposites based on PEO and CNT are perspective materials for the use as sensors of tension for the embedded sensory systems in different objects due to their unique descriptions which are caused by the change of resistance from the added external loading.

This work is devoted to study of influence of external pressure on conductivity of polymeric nanocomposites based on PEO and CNT, and also the detailed description of the mechanisms of action of pressure on forming of the conduct clusters.

\section{Experimental}

Model nanofilled systems based on polyethylene oxide and carbon nanotubes were used for research.

Polyethylene oxide (PEO 10000), $\mathrm{HO}\left[-\mathrm{CH}_{2}-\mathrm{CH}_{2}-\mathrm{O}-\right]_{n} \mathrm{H}(n \approx 225)$ with a molecular mass of $M_{w}=10000$ (Aldrich) was used as a polymer matrix. At $T=293 \mathrm{~K}$ PEO-10000 is a hard substance and its density is $\rho_{n}=1070 \mathrm{~kg} / \mathrm{m}^{3}$. It has a melting point of $T_{m} \approx 335-338 \mathrm{~K}$. Before using PEO 10000 was dewatered by heating in vacuum $(2 \mathrm{~mm})$ at residual pressure $P=270 \mathrm{~Pa}$ and temperature $T=353-373 \mathrm{~K}$ during $5 \mathrm{~h}$.

The multi-walled carbon nanotubes were prepared from ethylene using chemical vapor deposition (CVD) method (TMSpetsmash Ltd., Kyiv, Ukraine) with FeAlMo as a catalyst [15]. They were further treated by alkaline and acidic solutions and washed by distilled water until reaching the distilled water $\mathrm{pH}$ values in the filtrate. The typical outer diameter $d$ of CNT was $20-40 \mathrm{~nm}$, their length $L$ ranged from 5 to $10 \mu \mathrm{m}$ and mean aspect ratio was $a=$ $L / d \approx 250 \pm 170$. The specific surface area $S$ of the powders determined by $N_{2}$ adsorption was $S=130 \pm 5 \mathrm{~m}^{2} / \mathrm{g}$. The specific electric conductivity $\sigma$ of the powder of CNT compressed at $15 \mathrm{TPa}$ was about $10 \mathrm{~S} / \mathrm{cm}$ along the axis of compression. The density of the CNT was assumed to be the same as the density of pure graphite, $\rho_{n}=2045 \mathrm{~kg} / \mathrm{m}^{3}$.

The composites were obtained by adding the appropriate weights of filler (CNT) to PEO 10000 at $T=353 \mathrm{~K}$ with subsequent 5 min sonication of the mixture using a UZDN-2T ultrasonic disperser at frequency of $22 \mathrm{kHz}$ and the output power of $400 \mathrm{~W}$. The series of samples with content of CNT within $0.2-1$ wt.\% (in further \%) were investigated. 


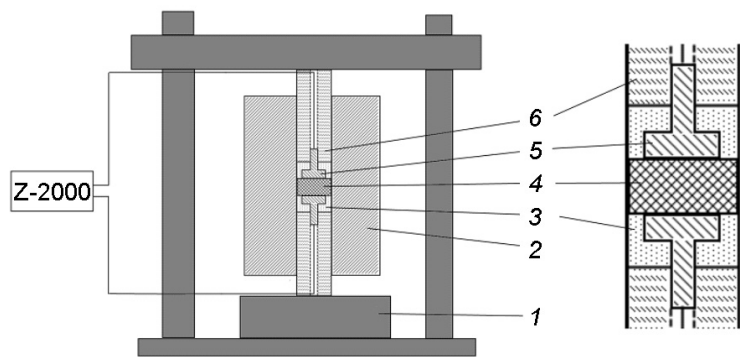

Fig. 1. Schematic image of the equipment based on hydrohammer and cell for investigation of conductivity of polymer nanocomposites under action of high pressure. 1 - Piston of press; 2 - an external restrictive cylinder; 3 - teflon gasket; 4 - sample; 5 electrode; 6 - a presser cylinder.

Investigation of conductivity of polymer nanocomposites based on PEO and CNT under the action of external pressure was done using the equipment based on hydrohammer (Fig. 1). The external pressure is varied in the range of $0.1-150 \mathrm{MPa}$. The construction of the cell is described in Fig. 1.

The nanocomposites conductivity was studied using impedance spectroscopy method on an impedancemeter Z-2000 (Elins, Inc., Russia). A sample was placed between the cell electrodes, and the real, $\mathrm{Z}^{\prime}$ and imaginary, $Z^{\prime \prime}$, parts of its impedance were measured. Following the technique described in work [16], $d c$ conductivity was determined from the complex impedance dependence, by using the formula $\sigma_{d c}=d / S R_{d c}$, where $S$ is the sample area, and $d$ its thickness. The measurements were carried out at the room temperature in the frequency range from $1 \mathrm{~Hz}$ to $2 \mathrm{MHz}$.

Each measurement was repeated, at least, five times for calculation of the mean values of experimental data.

\section{Results and discussion}

Fig. 2 presents the dependence of conductivity of the systems based on PEO and CNT on external pressure. For neat PEO the conductivity decreases with the pressure increase (Fig. 2, curve 1). This fact can be explained by that at the increase of pressure amorphous areas in semi-crystalline PEO are considerably made more compact; here a the free volume decreases in these areas. As known, the basic type of conductivity in neat PEO is ionic, and the charge transfer realizes mainly in amorphous areas by the hopping mechanism or by the mechanism of free volume [17].

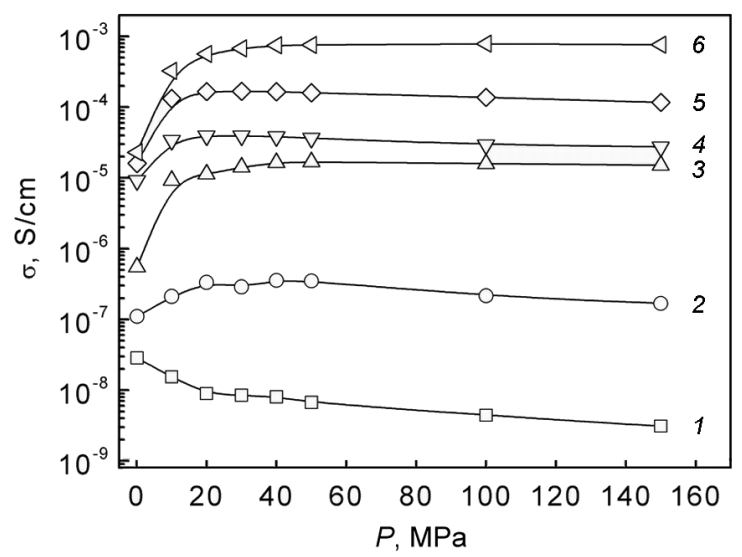

Fig. 2. Conductivity vs. external pressure for systems based on PEO, which contain CNT: $1-0 \% ; 2-0.2 \% ; 3-0.4 \% ; 4-0.6 \%$; $5-0.8 \% ; 6-1 \%$.

The dependences of conductivity on pressure (Fig. 2, curves 2-6) show extreme behavior. Conductivity grows swiftly, arriving the maxima at some values of pressure $\left(P_{c r}\right)$, and then falls gradually. Hussain et al. observed such a behavior in the silicon rubber-carbon black systems [7, 8]. It is explained, at first, by diminishing the distance between conductive filler, and then by the rebuilding of conductive cluster.

The conductivity behavior with the change of the external pressure of the system can be described within the framework of classic core-shell model. For example, Mamunya et al. used such approach for description of the dependence of conductivity on external pressure for powders of metals, in which the particle of metal was presented as a core, and the thin oxide films with low conductivity on their surface was presented as shells [19]. This approach can be adapted for description of processes of the charge transfer, which take place in the polymer-CNT systems. The composite conductivity does not depend on pressure, it is more lower than critical pressure $T_{c r}$, when a non-conducting polymeric layer between nanotubes is thick enough (more than $10 \mathrm{~nm}$ ). In this case, the charge transfer through this layer cannot realize by the tunneling mechanism which is possible when the polymeric layer is very thin (about few nanometers). At achievement of some critical pressure in the system, the fillers begin to form the "continuous" clusters that results in the sharp increase of conductivity. Such behavior is similar to the percolation behavior. Using such analogy, for description of the dependence of conductivity from 


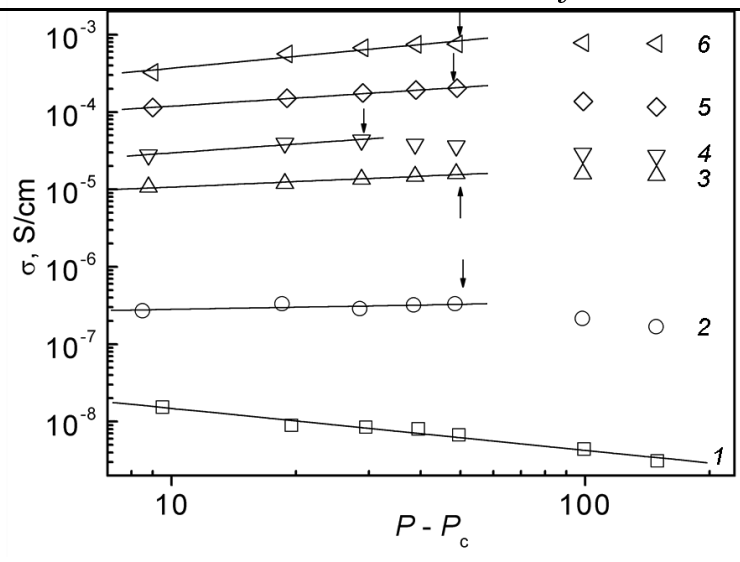

Fig. 3. Conductivity vs. external pressure in the coordinates of Eq. (2) for systems based on PEO, which contain CNT: $1-0 \% ; 2-$ $0.2 \% ; 3-0.4 \% ; 4-0.6 \% ; 5-0.8 \%$; $6-1 \%$. Solid line - approximation of Eq. (2).

external pressure for the nanofilled systems it is possible to use the classic scaling law $[20,21]$ :

$$
P(x) \propto\left(x-{ }_{c}\right)^{y},
$$

where $P(x)$ is the probability of percolation cluster formation, $x$ is variable argument (for example, temperature, concentration and others), $x_{c}$ is percolation threshold, $y$ is some critical exponent.

Writing the Eq. (1) in the term of investigating quantities, we will get an equation for description of the dependence of conductivity on external pressure for the polymeric nanocomposite systems:

$$
\sigma=k\left(P-P_{c}\right)^{n},
$$

where $k$ is a constant which depends on hardness of material and characterizes the conductivity of the system near the percolation threshold, $n$ is a the critical exponent. Mamunya et al. used such equation for the analysis of dependence of conductivity on pressure for powders of metals [19].

Fig. 3 shows dependences of conductivity of the systems, filled by CNT, on pressure in the coordinates of Eq. (2). The parameters of Eq. (2) are gotten using the linear approximation of the data in Fig. 3 and are presented in Table. The conclusion from the results of approximation is that Eq. (2) well describes experimental data in the range of pressures from $P_{c}$ to some critical pressure, $P_{c r}$, which are presented in Table and shown by arrows in Fig. 3 for different concentrations of CNT.

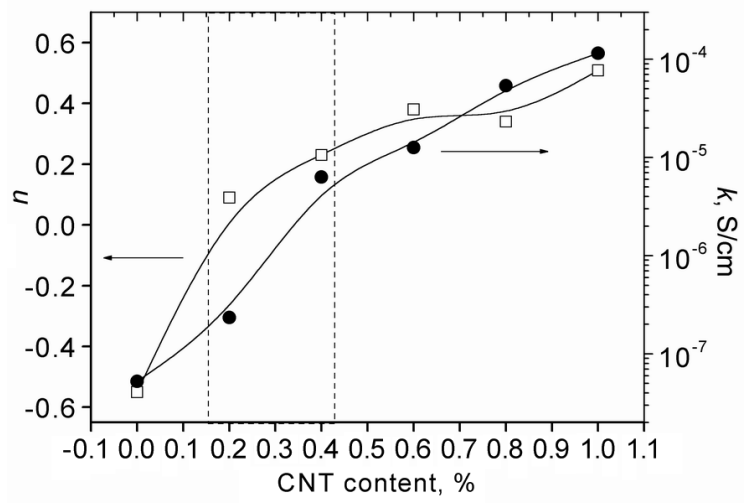

Fig. 4. Parameters of Eq. (2) vs. CNT content for the systems based on PEO.

Table. Values of parameters of Eq. (2)

\begin{tabular}{|c|c|c|c|c||}
\hline $\begin{array}{c}\mathrm{CNT} \\
\text { content, } \%\end{array}$ & $k, \mathrm{~S} / \mathrm{cm}$ & $P_{c}, \mathrm{MPa}$ & $n$ & $\begin{array}{c}P_{c r}, \\
\mathrm{MPa}\end{array}$ \\
\hline 0 & $5.2 \cdot 10^{-8}$ & 0.5 & -0.55 & - \\
0.2 & $2.3 \cdot 10^{-7}$ & 1.0 & 0.09 & 50 \\
0.4 & $6.3 \cdot 10^{-6}$ & 1.2 & 0.23 & 50 \\
0.6 & $1.3 \cdot 10^{-5}$ & 1.2 & 0.38 & 30 \\
0.8 & $5.4 \cdot 10^{-5}$ & 1.5 & 0.34 & 50 \\
1 & $1.2 \cdot 10^{-4}$ & 2.0 & 0.51 & 100 \\
\hline
\end{tabular}

Dependence of parameters of Eq. (2) from the CNT content is shown in Fig. 4. Fig. 4 demonstrates, that the values of parameters $k$ and $n$ change nonlinear with increase of nanotubes' content in the system. In the concentrations range of CNT from 0.15 to $0.45 \%$ there is a considerable increase of the values of parameters $k$ and $n$. In the same range of concentration the percolation transition is observed for PEO10000-CNT system and the percolation threshold is equal $0.3 \%$ [3]. Thus, parameters of Eq. (2), which are the mediated description of the material's hardness, show the percolation behavior.

The model for explanation of mechanism of external pressure influence on conductivity of PEO-CNT system (Fig. 2) is represented schematically in Fig. 5. The rapid increase of conductivity at small pressures (less from $P_{c r}$ ) can be explained by two basic factors: by the change of conductivity of the individual cluster from nanotubes and by the change of amount of the conducting clusters [7].

The increase of conductivity of the individual cluster takes a place due to the de- 

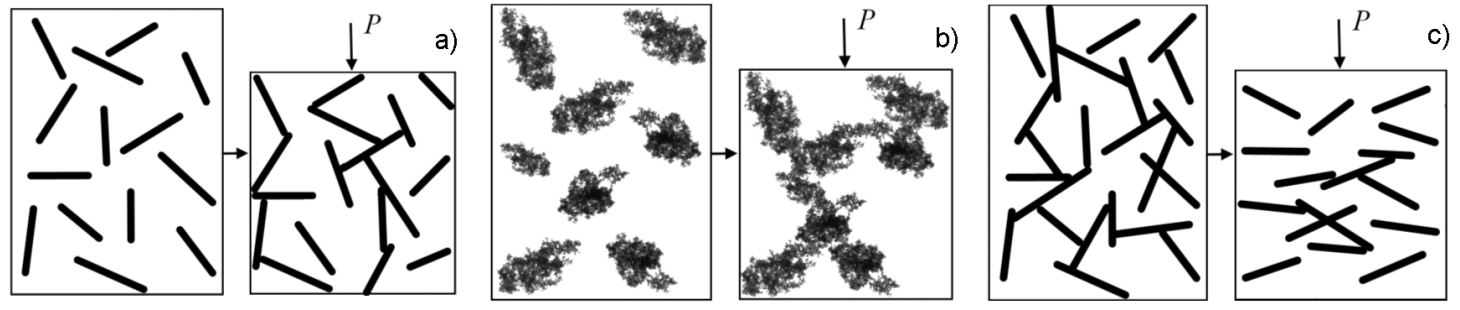

Fig. 5. Schematic image of pressure effect on the conductive CNT clusters formation.

crease of thickness of the polymeric layer between CNT to the values of distances when realization of the tunneling mechanism is possible (Fig. 5, a). The increase in amount of the conducting clusters takes place due to the diminishing of intervals between the separate clusters that allows clusters to unite and form "continuous" percolation cluster (Fig. 5, b). The gradual decrease of conductivity at large pressures (greater than $P_{c r}$ ) it is possible to explain by destruction or reorientation of the conducting clusters. Under act of the high external pressure, the molecular layers of polymer compact considerably. When the pressure of these layers acts on separate nanotubes, the transverse slippage of aggregates, caused by the external pressure, leads to the destruction of effective conductive paths (Fig. 5, c). As reported in [7], the separate aggregates from CNT can also orient. The critical pressure at which the behavior of dependence on conductivity changes is an important description of creation of sensors based on polymeric nanocomposites, which, actually, determines the limit of their application. It is shown in Table that, in general, $P_{c r}$ increases with increase of the CNT content in the system, however, at the certain CNT concentrations, it decreases. For the system of silicon rubber-carbon black, $P_{c r}$ increases with increase of the CNT content linearly [7]. For PEOCNT system, the nonlinear behavior of $P_{c r}$ with the CNT content increase can be explained by the presence of percolation transition in the range of investigated concentrations of the filler.

\section{Conclusions}

The influence of external pressure on conductivity for the systems based on polyethylene oxide and carbon nanotubes was studied. It is revealed that the conductivity of neat PEO decreases with the increase of pressure. That is related to the decrease of free volume, which is the base for charge transfer realization. It is shown that with the pressure increase, conductivity of the nanofilled systems shows the extreme behavior: it grows swiftly and arrives the maxima at some values of pressure, and then falls gradually. This phenomenon is explained by three basic factors: the change of conductivity of the individual cluster from nanotubes; the change of amount of conducting clusters and sliding of separate nanotubes and their perpendicular orientation to the direction of compression force action which results in destruction of the conducting clusters. The scheme, which explains the extreme change of conductivity with the increase of pressure, is offered. It is educed that the sharp increase of conductivity is observed at the achievement of some critical pressure in the system. That is related to forming the "continuous" clusters from the nanotubes. An analogy is conducted between the dependence of conductivity on external pressure and classic percolation behavior of the nanofilled systems. Such analogy allows to describe dependences $\sigma(P)$ within the framework of scaling equation with the high exactness for the prognostication of piezoresistive properties of the nanocomposite polymeric materials.

\section{References}

1. D.R.Paul, L.M.Robeson, Polymer, 49, 3187 (2008).

2. G.Mittal, V.Dhand, K.Y.Rhee et al., J.Indust. Engin.Chem., 21, 11 (2015).

3. E.Lysenkov, I.Melnyk, L.Bulavin et al., Physics of Liquid Matter: Modern Problems, Springer Proc. in Physics, ed. by L.Bulavin, N.Lebovka, Springer Intern. Publishing, Switzerland (2015), p.165.

4. W.Bauhofer, J.Z.Kovacs, Compos.Sci.Technol., 69, 1486 (2009).

5. L.Lisetski, M.Soskin, N.Lebovka, Physics of Liquid Matter: Modern Problems, Springer Proc. in Physics, ed. by L.Bulavin, N.Lebovka, Springer Intern. Publishing, Switzerland (2015), p.242.

6. L.A.Bulavin, N.I.Lebovka, Y.A.Kyslyi et al., Ukr.J.Phys., 55, 1 (2010). 
7. W.Luheng, D.Tianhuai, W.Peng, Sens. and Actuat. A, 135, 587 (2007).

8. W.Obitayo, T.Liu, J.Sens., ID 652438 (2012).

9. A.Ramaratnam, N.Jalili, J. Intel. Mater. Syst. Struct., 17, 199 (2006).

10. I.Kang, M.J.Schulz, J.H.Kim et al., Smart Mater. Struct., 15, 737 (2006).

11. M.Park, H.Kim, J.P.Youngblood, Nanotechnology, 19, 055705 (2008).

12. E.A.Lysenkov, V.V.Klepko, J.Nano-Electron. Phys., 5, 03052 (2013).

13. V.V.Klepko, E.A.Lysenkov, Ukr.J.Phys., 60, 944 (2015).

14. E.A.Lysenkov, V.V.Klepko, V.M.Golovanets et al., Ukr.J.Phys., 59, 906 (2014).
15. A.V.Melezhyk, Yu.I.Sementsov, V.V.Yanchenko, Prikl. Khim., 78, 938 (2005).

16. A.Kyritsis, P.Pissis, J.Grammatikakis, $J$. Polymer Sci.:Part B: Polymer Phys., 33, 1737 (1995).

17. E.A.Lysenkov, V.V.Klepko, Ukr.J.Phys., 56, 484 (2011).

18. M.Hussain, Y.-H.Choa, K.Niihara, Composites: Part A, 32, 1689 (2001).

19. Ye.P.Mamunya, H.Zois, L.Apekis et al., Powder Technol., 140, 49 (2004).

20. D.Stauffer, A.Aharony, Introduction to Percolation Theory, Taylor and Francis, London (1994).

21. M.Sahimi, Applications of Percolation Theory, Taylor and Francis, London (1994). 